Research.

\title{
Corporate social responsibility disclosure, good corporate governance, firm value: evidence from Indonesia's food and beverage companies
}

\author{
Martina M. Putri'); Amrie Firmansyah ${ }^{2)^{*}}$; Dolly Labadia ${ }^{3)}$ \\ 1,2,3 Polytechnic of State Finance STAN, Indonesia. \\ amrie.firmansyah@gmail.com \\ * Corresponding author
}

Received: October 23, 2020; Accepted: November 20, 2020; Published: December 31, 2020

To cite this article: Putri, M. M., Firmansyah,A \& Labadia,D. (2020). Corporate Social Responsibility Disclosure, Good Corporate Governance, Firm Value: Evidence From Indonesia's Food And Beverage Companies. The Accounting Journal of BINANIAGA. 5 (2), 113-124 doi: 10.33062/ajb.v5i2.398

\begin{abstract}
This study analyzes the relation between CSR disclosure and GCG to the firm value of Indonesia's food and beverage companies. The study is designed as quantitative research based on a multiple linear regression model. This research sample consists of 20 food and beverage companies that meet the criteria of having complete financial statements and annual report for the year 2018 and 2019 with a total of 40 observations. The result suggests that CSR disclosure has a significant effect on firm value. On the contrary, GCG does not affect firm value. These findings reflect that Indonesia's food and beverage companies should improve CSR implementation if they intend to obtain a positive response from the market. Also, the company should evaluate the implementation of GCG, not only aim to comply with the regulation, but also to enhance its quality.
\end{abstract}

Keywords: CSR, Disclosure, GCG, Firm value.

\section{INTRODUCTION}

Each company has a primary purpose in running its business. Generally, it is a profit motive. To earn the maximum profit, some companies decide to release their ownership in the capital market to obtain profit through funding. The companies have to compete with each other to increase and have better firm value in the competitive business world at this time. Firm value is the success of a company associated with investors' share value (Fatimah et al., 2019). The value of the company's shares reflects valuable the company from the investors' perspective.

The capital market in Indonesia has experienced remarkable development over the last few years. From November 28, 2018, to August 9, 2019, there was an increase in trading liquidity represented by the volume, value, and frequency of daily stock transactions, which increased by 35 percent for daily transaction volume, the average daily stock transaction value increased by 16 percent, and the frequency of daily stock transactions increased by 17 percent compared to the previous one year period (Sugianto, 2019). This fact indicates that stock trading in Indonesia has attracted more investors.

In deciding to invest, investors consider the information they receive about the company. Signaling theory describes some intentionally sent signals by high-profile companies, hoping that the market can differentiate between good and bad quality companies (Fatchan \& Trisnawati, 2016). These signals are stated explicitly or implicitly in the financial statements. By looking at them, investors may identify the company's state so

Martina M. Putri, Amrie Firmansyah and Dolly Labadia, Corporate Social Responsibility Disclosure, Good Corporate Governance, Firm Value: Evidence From Indonesia's Food And Beverage Companies 
that they can determine whether the company has high value and to make a decision about the investment.

The response given by investors is currently not only influenced by the financial condition of the company. As the company's performance increases, it also raises the possibility of social and environmental issues. These negative impacts cause critical responses from the community and become the attention of investors. If a company cannot manage the possibility of negative impacts that arise, it is considered that the company is not sustainable. Nuryana \& Bhebhe (2019) stated that Corporate Social Responsibility (CSR) is a strategy that cannot be felt in the short term, but rather a long-term strategy of the company to maintain its sustainability. Also, the role of management in managing the company attracts the attention of investors. Good Corporate Governance (GCG) is a principle that directs and controls the company in order to achieve a balance between the strength and authority of the company in providing accountability to interested parties, shareholders in particular, and stakeholders in general (Syafitri et al., 2018). By having good company management, the company's performance is expected to increase, which will lead to an increase in profit a company makes.

Several previous studies about CSR disclosure have been conducted, but there were inconsistencies in the results. Bawafi \& Prasetyo (2015) state that CSR is empirically proven to affect firm value significantly. This statement is in line with the research results by Murnita \& Putra (2018), which states that CSR has a positive effect on firm value. On the other hand, Nuryana and Bhebhe (2019) revealed that CSR disclosure does not affect firm value. As with CSR, previous studies on GCG also show differences in results. Mukhtaruddin et al. (2014) find that GCG projected with managerial ownership has a significant positive effect on firm value.

Meanwhile, Muliani et al. (2014) suggested conflicting results. The research states that the higher the managerial ownership, the lower the firm value will be. The two results of this study are different from the research of Estiasih et al. (2019), which states that the effect of GCG implementation on firm value is not significant.

Companies in the food and beverage subsector have good investment prospects as food and beverage are nearly primary and basic human needs. Malia (2020) stated that the manufacturing sector is the most attractive investment sector, with the food and beverage subsector in the first rank. During the last five years (2015 - first quarter of 2020), the realization of food and beverage subsector investment reaches IDR 293.2 trillion of a total investment of IDR 1,348.9 trillion in the manufacturing sector, equivalent to a total investment percentage of 21.7 percent. On average, the realization of investment in the food and beverage sub sector increases by 3 percent each year.

The food and beverage subsector companies are also closely related to economic, social, and environmental issues. The more the company grows, it indicates the development of production in companies and the consumption in society. It will increase the waste left behind, which may cause environmental contamination. Also, similar to other manufacturing sectors, companies in the food and beverage subsector are laborintensive, so that issues of employment, occupational safety and health, and equality of opportunity are the essential factors related to the sustainability of the companies.

This study aims to provide actual and comprehensive results about the effect of CSR disclosure on firm value by implementing GRI Standards 2018, the latest guideline on sustainability reporting, as a measurement. Considering it is new guidance that not many earlier studies used, this study is expected to provide an additional perspective on this issue and benefit the researchers in the future. This study also aims to show more specific results about GCG in Indonesia by applying OJK Circular Letter No. 32/SEOJK.04/2015 to evaluate its implementation and its relation to the firm value.

Martina M. Putri, Amrie Firmansyah and Dolly Labadia, Corporate Social Responsibility Disclosure, Good Corporate Governance, Firm Value: Evidence From Indonesia's Food And Beverage Companies 


\section{LITERATURE REVIEW}

Firm value is a specific condition achieved by a company representing public trust in a company activity that has been going on for years (Fajari \& Isynuwardhana, 2019). For companies listed on the stock exchange, the firm value is identified by the outstanding shares' market price. The stock market value is formed from the bargaining process. It occurs because the public assesses the company's past performance. It is carried out by processing the data presented in the financial statements using financial ratios. One of the data that can be processed is asset data. The greater the market value of the company's assets compared to the book value of the company's assets, the greater the willingness of investors to make more sacrifices to own the company (Sukamulja, 2004 in Fauzi et al., 2016). Derived from the explanation, the firm value, which is described by the rise and fall of stock prices, illustrates public confidence in its ability to manage its performance. The high stock market price reflects public trust in the company. It lies not only in the company's current performance but also in the company's growth prospects in the future.

The World Commission introduced sustainable development on Environment and Development (WCED) in the Brundtland Report (1987). WCED develops three integrated aspects in the concept of sustainable development; they are economic growth, environmental protection, and social equity. This concept is then known as the triple bottom line, popularized by John Elkington (1994). A year later, Elkington returned to formulate it with the term $3 \mathrm{P}$, which stands for Profit, People, and Planet. Based on this concept, the balance between economic benefits, the environment, and public welfare is a crucial matter that must be fulfilled by companies so that the company can sustain itself in the long term. The manifestation of this balance is then described in the form of CSR. In Indonesia, CSR has been regulated in the Law No. 40 of 2007 on Limited Liability Companies. It is defined as a company's commitment to participate in sustainable economic development, improving the quality of life and a beneficial environment for the company, the local community, and society. Each company that carries out its business activities in the fields and related to natural resources is obliged to implement CSR, and there are sanctions for companies that do not implement it. Based on the description above, it is concluded that CSR disclosure is a company publication relating to its economic, social, and environmental activities that affect not only the society but also the sustainability of the company.

According to the Cadbury Committee, Good Corporate Governance (GCG) is a principle of directing and controlling the company to balance the strength and authority. It gives its accountability to stakeholders in particular and stakeholders in general (Hamdani, 2016). Inadequate management supervision can affect public confidence in the stock market. One of the most significant cases of this, the Enron case, was the cause the Sarbanes-Oxley Act was drafted. It regulates companies' governance in the United States so that financial scandals will not occur again in the future, and public confidence in the stock market can return. In Indonesia, the concept of GCG has become known since the economic crisis in 1997, a prolonged crisis caused by companies' inability to manage responsibly and ignoring regulations and full of corruption, collusion, and nepotism practices (Budiati, 2012). For this reason, the government formed the National Committee for Corporate Governance in 2001, which was later changed to the National Committee for Governance Policy to expand the scope of governance to the public sector. Accordingly, it is concluded that GCG regulates the relationship between managers and shareholders to maintain its sustainability and adequate management supervision.

In signaling theory, positive information can improve the company's image. Investors capture it as an advantage that can increase firm value. Several studies have shown that CSR enhances a company's image. If the company implements its social responsibility sustainably

Martina M. Putri, Amrie Firmansyah and Dolly Labadia, Corporate Social Responsibility Disclosure, Good Corporate Governance, Firm Value: Evidence From Indonesia's Food And Beverage Companies 
and consistently, its image on the company's external side will be better (Murnita \& Putra, 2018). Muliani et al. (2014) find that CSR disclosure has a significant positive effect on firm value. The same result is also found in research conducted by Marius and Masri (2017). Therefore, based on previous studies following the signaling theory, this study expects CSR disclosure carried out by food and beverage subsector companies in Indonesia improves its image and leads to an increase of the firm value. Therefore, the first hypothesis in this study is:

$H_{1}$ : CSR disclosure has a positive effect on firm value.

GCG arises because of fraud committed by management in handling the company. The fraud causes loss to the company and reduces public confidence in the capital market. Mukhtaruddin et al. (2014) find that GCG, which is proxied by managerial ownership, and the audit committee has a significant positive effect on firm value. A similar result is also presented by Sunardi (2019), where institutional ownership, managerial ownership, independent commissioners, and the audit committee had a simultaneously significant positive effect on firm value. Based on the objectives of implementing GCG and previous research, this study shows that GCG may increase company value. Therefore, the second hypothesis in this study is:

$H_{2}$ : GCG has a positive effect on firm value.

\section{RESEARCH METHODOLOGY}

The population studied in this study consists of the food and beverage companies listed on the Indonesia Stock Exchange. Using the following criteria, a purposive sampling method was adopted: conduct Initial Public Offering (IPO) before January 1, 2018, and companies that have published complete financial reports and annual reports for the years 2018-2019. The final sample comprised of 424 observations. After removing the outlier, the final sample comprised 40 observations. (Table 1)

Table-1. Sample selection summary

\begin{tabular}{lc}
\hline Criteria & Observations \\
\hline Manufacturing companies classified in the food and beverage subsector on & 23 \\
Indonesia Stock Exchange & \\
Food and beverage subsector companies that have complete financial report & 21 \\
data and annual reports for 2018-2019 & $(1)$ \\
Outlier & 20 \\
Companies observed & 2 \\
Research year/period & 40 \\
\hline Number of research samples over two years (2018-2019) & \\
\hline
\end{tabular}

This study's dependent variable was firm value as measured by Tobin's $Q$ ratio as a proxy, follows Firmansyah \& Ardi (2020), Firmansyah \& Purnama, Novianti \& Firmansyah. The Tobin's $Q$ ratio was chosen to be used as a proxy because the Tobin's $Q$ ratio can provide an overview of the company's fundamental aspects and the market view of the company. Tobin's $Q$ ratio measures the effectiveness of management in managing the company's economic resources. This ratio is a valuable concept because it shows current financial market estimates of the return on each dollar of incremental investment (Fauzi et al., 2016).

This study uses three independent variables to represent the factors likely to influence the firm value. The first independent variable, CSR, was measured based on the Global Reporting Initiative (GRI) Standard, which has been in effect since July 1, 2018. This index was divided into three categories: 31 sub-categories with 70 items according to Appendix 1 of this study. This measurement was conducted by giving a value of 1 for each item that the company discloses, otherwise 0 . These values were added to obtain the overall score for each company to be further divided by the total number of items.

The second independent variable, GCG, was measured by creating an index consisting of eight main measurement principles according to the GCG Guidelines for Public Companies issued by OJK (Indonesia Financial Services Authority) through Circular Letter No.

\footnotetext{
Martina M. Putri, Amrie Firmansyah and Dolly Labadia, Corporate Social Responsibility Disclosure, Good Corporate Governance, Firm Value: Evidence From Indonesia's Food And Beverage Companies
} 
32/SEOJK/04/2015 in 2015. This index was divided into eight categories, with 25 items according to Appendix 2 of this study. It is conducted by providing a value of 1 for each item that the company discloses, otherwise 0 . It is further divided by the total number of items.

The third independent variable was the firm value before the research year $(\mathrm{t}-1)$, which acts as a control variable. With control variables, errors that may arise can be minimized. The errors in question, for example, are in the form of errors in designing the model, errors in data entry or analysis, and other minor errors of the same type (Chandrarin, 2017). The regression model tested in this study was as follows: Where:

TOBINQ $Q_{i t}=\alpha_{i t}+\beta_{1}$ CSRDI $_{i t}+\beta_{2} \mathrm{GCG}_{i t}+\beta_{3} \mathrm{TOBINQ}_{\mathrm{it}-1}+\varepsilon_{\mathrm{it}}$

TOBINQ $\quad=$ Firm Value

CSRDlit $_{\text {I }} \quad=$ Corporate Social Responsibility Disclosure

GCG $\quad=$ Good Corporate Governance Disclosure

TOBINQ

\section{RESULTS AND DISCUSSION}

The descriptive statistics for each variable are shown in Table 2. In Indonesia, the average firm value of food and beverage companies from 2013 to 2016 was 2.660996. It shows a tendency for food and beverage companies in Indonesia to have higher company values than their book values in 2018-2019. Over the same two-year period, the average size for CSR disclosure of food beverage and companies in Indonesia was 0.2389 , and with the median value being 0.1928 , indicated that most still required to disclose better and perform their CSR. Then, GCG disclosure, with the average value being 0.57900 and median value being 0.740000 , indicated that most are still required to disclose better and perform their CCG.

Table-2. Descriptive statistics

\begin{tabular}{cccccc}
\hline Variables & Mean & Median & Maximum & Minimum & Std. Dev. \\
\hline TOBINSQ & 2.6609 & 2.0414 & 12.3382 & 0.5021 & 2.5490 \\
CSRDI & 0.2389 & 0.1928 & 0.7000 & 0.0428 & 0.1671 \\
GCG & 0.5790 & 0.7400 & 1.0000 & 0.0000 & -0.2491 \\
TOBINSQt-1 & 2.7367 & 2.0685 & 12.3552 & 0.7374 & 2.5123 \\
\hline
\end{tabular}

A multicollinearity test was conducted to determine whether any correlation existed between the regression model's independent variables. According to Ghozali (2016), the correlation between variables is relatively high when its value exceeds 0.9 , and as is evident from the correlation matrix in Table 3 , there is no such relationship between the variables in this study. It is thus concluded that this study is free from the problem of multicollinearity.

Table-3. Correlation matrix

\begin{tabular}{cccc}
\hline Variables & CSRDI & GCG & TOBINSQt-1 \\
\hline CSRDI & 1.000000 & 0.442161 & 0.343622 \\
GCG & 0.442161 & 1.000000 & 0.094500 \\
TOBINSQt-1 & 0.343622 & 0.094500 & 1.000000 \\
\hline
\end{tabular}

The regression results shown in Table 4 show that two variables significantly influence the firm value. CSR disclosure has positive coefficients, supporting hypotheses $\mathrm{H}_{1}$; however, the coefficients for GCG disclosure levels are negative, rejecting hypotheses $\mathrm{H}_{2}$.

Table-4. Regression test results

\begin{tabular}{lcccc}
\hline Variables & Prediction & Coefficient & t-Stat & Prob. \\
\hline CSRDI & + & 1.2712 & $2.0704^{* *}$ & 0.0270 \\
\hline GCG & + & -1.8482 & $-2.7355^{* * *}$ & 0.0070 \\
\hline TOBIN_S_Q_1 & & 0.1644 & $1.7579^{*}$ & 0.0483 \\
\hline Constant & & 2.9773 & $3.8621^{* * *}$ & 0.0006 \\
\hline
\end{tabular}

Martina M. Putri, Amrie Firmansyah and Dolly Labadia, Corporate Social Responsibility Disclosure, Good Corporate Governance, Firm Value: Evidence From Indonesia's Food And Beverage Companies 


\begin{tabular}{|c|c|c|c|c|}
\hline Variables & Prediction & Coefficient & t-Stat & Prob. \\
\hline $\mathrm{R}^{2}$ & 0.99 & & & \\
\hline Adj. $R^{2}$ & 0.99 & & & \\
\hline F-Stat. & 3500.11 & & & \\
\hline Prob. (F-Stat.) & 0.000 & & & \\
\hline
\end{tabular}

\section{CSR disclosure is positively associated with firm value.}

The result suggests that the first hypothesis is supported. CSR disclosure has a significant positive effect on a firm value indicating that CSR practices carried out by companies are one of the considerations taken into account by the public. It is in line with the research of Bawafi and Prasetyo (2015), but not in line with Nuryana \& Bhebhe (2019), which revealed that CSR disclosure has no significant effect on firm value. Although the research results show that CSR disclosure, according to GRI proxies for food and beverage companies in Indonesia, is still low, most companies have carried out CSR activities based on GRI's social categories. It can increase public awareness of the company's ability to demonstrate its commitment to the quality of social life and a sustainable economy and the environmental impact of its operations.

In addition to this, CSR is an activity whose benefits are directly obtained by the community. Every CSR activity is documented by the company and provides substantial assistance to the community in funds and facilities. Companies that carry out CSR can be said to have healthy finances because they can set aside their resources to carry out non-profit activities. Companies that carry out CSR are considered capable of contributing and being responsible for their activities. It is taken into account as a guarantee that the company's value will grow sustainably.

These results are in line with the signaling theory. The public thinks that CSR's information presented in the annual report is positive information that provides a positive image for the company. CSR is considered to be able to build public trust. High trust has a positive impact on company value. Although the impact cannot be felt directly, this can be a company strategy to increase its value in the long term.

\section{GCG disclosure is positively associated with firm value.}

According to the test result, the second hypothesis is rejected. GCG disclosure does not affect company value, indicating that the company's GCG practices have not become one of the considerations taken into account by the public. It is in line with Fatchan \& Trisnawati (2016), but not in line with the research of Mukhtaruddin et al. (2014), who found that GCG has a significant positive effect on firm value.

The development of GCG is motivated by the existence of gaps in fraud that can be carried out by large companies' management in running their companies. Management can modify the financial statements so that the company's financial statements appear to have good performance. The existence of GCG is expected to prevent these frauds. It underlies the hypothesis in this study, namely that GCG has a positive effect on firm value. However, this study gave conflicting results.

Hypothesis test results show that GCG implementation is proxied by an index based on the attachment to OJK Circular Letter No. 32/SEOJK.04/2015 does not affect the value of the food and beverage sub-sector company. It illustrates that investors have not considered GCG as a consideration in investing in a public company. The disclosure of GCG presented in the company's annual report has not fully caught investors' attention. It means that financial performance is still something that attracts investors' attention to investing.

Unlike CSR, whose benefits can be felt directly by the community, GCG tends to have no real benefits to society. GCG is still seen as an administrative act that has no benefit to the community. This study also illustrates that the implementation of GCG is still only seen as a formality required for fulfilling regulations. In other words, companies in Indonesia implement GCG solely because of the circular issued by the OJK. Fatchan \&Trisnawati (2016) stated that

Martina M. Putri, Amrie Firmansyah and Dolly Labadia, Corporate Social Responsibility Disclosure, Good Corporate Governance, Firm Value: Evidence From Indonesia's Food And Beverage Companies 
the implementation of GCG by companies in Indonesia is limited to only following the government's minimum regulations to not the desire of the company itself. Also, the results of this study's observations indicate that based on the annual report, not all food and beverage subsector companies have implemented GCG following the attachment to the OJK Circular Letter No 32/SEOJK.04/2015. Even though it has been in effect since November 17, 2015, several companies do not disclose GCG in their annual reports.

\section{CONCLUSION \& RECOMMENDATIONS}

This study measures the firm value of food and beverage companies listed on the Indonesia Stock Exchange and examines the influence of CSR disclosure and GCG. It is found that while the CSR disclosure positively affects firm value. However, GCG disclosure does not affect firm value. Despite OJK Circular Letter No. 32/SEOJK.04/2015 has been in effect since November 17, 2015; several companies have not disclosed GCG in their annual reports. According to the results of this study, CSR can increase firm value in the long term because CSR implementation can also add positive value to society and investors. This study also suggests the GCG in the company has not been appropriately implemented, or the company is still not serious about implementing GCG.

There are limitations to this research, in any case. First, determining the CSR and GCG disclosure scores are conducted from the researchers' perspectives only. No other party is involved in confirming the validity and reliability of the outcomes. Second, although the CSR and GCG scores are based on predefined criteria, subjectivity in the researchers' scoring cannot be avoided. Third, since GRI Standards has just become effective, there are a limited number of companies and periods to be researched. Only 20 companies with a span of two years of financial and annual report data are used. It is suggested that future research may expand on the objectives of this study and the sample of this study, include more indicators to measure firm value, use different independent variables (i.e., earnings management), and other proxies that can reflect the management policies.

Based on the results of this study, it shows that companies need to pay attention to CSR activities that can provide positive values for the company. This activity can also be used as a long-term strategy to maintain its competitive advantage in the future. Companies need to improve the quality of GCG not only to meet administrative requirements under the guidelines. High-quality GCG is useful for improving company performance and obtaining a positive response from the market.

\section{REFERENCES}

Bawafi, M. H., \& Prasetyo, A. (2015). The effect of corporate social responsibility disclosure on firm value with profitability as a moderating variable. Journal of Financial Accounting Review, 5(1), 721-730. doi:https://doi.org/10.22219/jrak.v5i1.4993

Budiati, L. (2012). Good governance in environmental management. Ghalia Indonesia.

Chandrarin, G. (2017). Accounting research methods: a quantitative approach. Salemba Empat.

Estiasih, P. E., Yuniarsih, N., \& Wajdi, M. B. N. (2019). The influence of corporate social responsibility disclosure, managerial ownership and firm size on firm value in indonesia stock exchange. International Journal of Innovation, Creativity and Change, 9(9), 159-171.

Martina M. Putri, Amrie Firmansyah and Dolly Labadia, Corporate Social Responsibility Disclosure, Good Corporate Governance, Firm Value: Evidence From Indonesia's Food And Beverage Companies 
Hamdani, M. (2016). Good corporate governance (gcg) in the perspective of agency theory. National Seminar of the Faculty of Economics, Universitas Terbuka. 279283.

Fajari, M. A., \& Isynuwardhana, D. (2019). The effect of good corporate governance and corporate social responsibility on firm value (study of industrial and consumer goods companies listed on indonesia stock exchange in 2014-2017). AKSARA PUBLIC Journal, 3(3), 89-100. url: http://www.aksarapublic.com/index.php/home/article/view/261

Fatchan, I. N., \& Trisnawati, R. (2016). The effect of good corporate governance on the relationship between sustainability reports and firm value (empirical study of go public companies in Indonesia 2014-2015 period). Indonesian Accounting and Financial Research, 1(1), 25-34. doi: https://doi.org/10.23917/reaksi.v1i1.1954

Fatimah, Mardani, R. M., \& Wahono, B. (2019). The effect of good corporate governance on firm value with financial performance as an intervening variable (case study on consumer goods sector manufacturing companies listed in bei 2015-2017). ejournal of Management Research Study Program Management, Faculty of Economics, Unisma, 8(15),51-69. http://riset.unisma.ac.id/index.php/jrm/article/view/4449

Fauzi, A. S., Suransi, N. K., \& Alamsyah. (2016). The effect of gcg and csr on firm value with profitability as a moderating variable. InFestasi Journal, 12(1), 1-19. https://journal.trunojoyo.ac.id/infestasi/article/view/1797

Firmansyah, A., \& Ardi, A. K. (2020). Related Party Transactions, Supply chain and Cost Management on Firm's Value: Evidence from Indonesia. International Journal of Supply Chain Management, 9(3), 1201-1209.

Firmansyah, A., \& Purnama E. D. B. (2020). Do derivatives instruments ownership decrease firm value in indonesia? Riset Akuntansi dan Keuangan Indonesia, 5 (1), 1-9.

Ghozali, I. (2016). Multivariate analysis application with IBM SPSS 21 program. Badan Penerbit Universitas Diponegoro.

Global Reporting Initiative. (2013). Reporting principles and standard disclosures. Global Reporting Initiative.

Gumanti, T. A. (2009). Signal theory in financial management. Journal of Indonesian Entrepreneur Management, 38(6), 4-13. https://scholar.google.co.id/citations?user=fOPMv5cAAAAJ\&hl=en

Malia, I. (2020, May 26). Most popular, investment in the manufacturing sector reached rp1,348.9 trillion. IDNTimes. https://www.idntimes.com/business/economy/indianamalia/paling-diminatiinvestasi-sektor-manufaktur-capai-rp13489-triliun/3

Marius, M. E., \& Masri, I. (2017). The influence of good corporate governance and corporate social responsibility on firm value. Accounting Scientific Conference IV, 1(2), 1-22. http://dosen.univpancasila.ac.id/

Martina M. Putri, Amrie Firmansyah and Dolly Labadia, Corporate Social Responsibility Disclosure, Good Corporate Governance, Firm Value: Evidence From Indonesia's Food And 
Mukhtaruddin, R., \& Felmania M. (2014). Good corporate governance mechanism, corporate social responsibility disclosure on firm value: empirical study on listed company in Indonesia stock exchange. International Journal of Finance \& Accounting Studies, 2 (1), 1-10. doi:http://dx.doi.org/10.7575/aiac.ijfas.v.2n.1p.1

Muliani, L. E., Yuniarta, G. A., \& Sinarwati, N. K. (2014). The effect of financial performance on firm value with disclosure of corporate social responsibility and good corporate governance as moderating variables (case study on indonesia stock exchange 2010-2012). e-Journal S1 Ak Ganesha Education University, Bachelor of Accounting Department, 2(1), 1-10. doi: http://dx.doi.org/10.23887/jimat.v2i1.3423

Murnita, P. E. M., \& Putra, I. M. P. D. (2018). Disclosure of corporate social responsibility on firm value with profitability and leverage as moderating variables. Udayana University Accounting E-Journal, 23(2), 1470-1494. doi: https://doi.org/10.24843/EJA.2018.v23.i02.p25

Novianti, T, \&, Firmansyah, A. (2020). The effect of tax risk, hedging, income smoothing, and cash flows volatility on firm value. Test Engineering and Management, 83, $9675-9686$.

Nuryana, I. \& Bhebhe, E. (2019). Disclosure of corporate social responsibility on firm value with profitability as a moderating variable. AFRE Accounting and Financial Review, 2(2), 142-146. doi: https://doi.org/10.26905/afr.v2i2.3261

Rokhlinasari, S. (2016). Theories in disclosing information on banking corporate social responsibility. Al-Amwal: Journal of Islamic Economics and Banking, 7(1), 1-11. doi: http://doi.org/10.24235/amwal.v7i1.217

Singgih, M., Farida, L., \& Iwanda, R. A. (2017). The determinant of the level of social responsibility disclosure in the food and beverage sub-sector manufacturing companies in bei. Bisma Journal of Business and Management, 11(3), 259-270. http://10.19184/bisma.v11i3.6320

Sugianto, D. (2019, August 12). 42 years of existence, this is the journey of indonesia capital market. DetikFinance. https://finance.detik.com/bursa-dan-valas/d4661850/42-tahun-berdiri-begini-perjalanan-pasar-modal-indonesia

Sugiyono. 2016. Quantitative, qualitative and r\&d research methods. Alfabeta.

Stiaji, R. J., Diana, N., \& Afifudin, A. (2017). The influence of corporate social responsibility on firm value with profitability as a moderating variable (empirical study on food and beverage companies listed in BEI 2013-2015). Scientific Journal of Accounting Research, 6(06).

Sunardi, N. (2019). Good corporate governance mechanism for firm value with leverage as an intervening variable in manufacturing companies listed on indonesia stock exchange in 2012-2018. Forkamma Management Scientific Journal, 2(3), 48-61. doi: http://dx.doi.org/10.32493/frkm.v2i3.3397

Syafitri, T., Nuzula, N. F., \& Nurlaily F. (2018). The effect of good corporate governance on firm value (studies on metal and the like industrial companies listed in bei 2012-2016 period). Journal of Business Administration (JAB), 56 (1), 118-126. http://administrasibisnis.studentjournal.ub.ac.id/index.php/jab/article/view/2327/

Martina M. Putri, Amrie Firmansyah and Dolly Labadia, Corporate Social Responsibility Disclosure, Good Corporate Governance, Firm Value: Evidence From Indonesia's Food And Beverage Companies 
The Accounting Journal of BINANIAGA Vol. 05, No. 02, December 2020

p-ISSN: 2527-4309, e-ISSN: 2580-1481

$5^{\text {th }}$ Accreditation Rating: January 14, 2019 - January 13, 2024

This page intentionally be emptied.

Martina M. Putri, Amrie Firmansyah and Dolly Labadia, Corporate Social Responsibility Disclosure, Good Corporate Governance, Firm Value: Evidence From Indonesia's Food And 